\title{
Top-bioclimate conditions associated with the natural occurrence of two Amazonian tree species for sustainable reforestation in the State of Para, Brazil
}

\author{
L. G. Martorano ${ }^{1}$, D. C. A. Monteiro ${ }^{2}$, S. Brienza Jr. ${ }^{1}$, \\ L. S. Lisboa ${ }^{3}$, J. M. do Espírito Santo $^{4}$ \& R. F. Almeida ${ }^{5}$ \\ ${ }^{1}$ Embrapa Eastern Amazon, Brazil \\ 2 "Luis de Queiroz College of Agriculture"/USP, Brazil \\ ${ }^{3}$ ITTO/Embrapa Project, Brazil \\ ${ }^{4}$ Forest Development Institute of the State of Para, Brazil \\ ${ }^{5}$ UFRA/EMBRAPA of Para, Brazil
}

\begin{abstract}
The plants' answer to the top-bioclimate conditions is important for mapping occurrences and indications of preferential areas for the development of the forest species. This study aimed to georeference the natural occurrence of Taxibranco (Sclerolobium paniculatum Vogel) and Parica (Schizolobium parahyba var. amazonicum (Huber ex Ducke) Barneby) integrated with top-bioclimate information to indicate plantations for rehabilitation of degraded landscape. The data regarding natural occurrence of species was investigated in the literature, the herbaria of Embrapa Eastern Amazon and the Paraense Emilio Goeldi Museum and demonstrative units in the Eastern Amazon. Normal climates from thirty year series with spatial resolution $3 \mathrm{~km}$ x $3 \mathrm{~km}$ were specialized in Arcgis 9.3 and exported to TerraView 3.2, to create the cellular space for integration of variables in TerraME and to generate top-climate maps and species' natural occurrence. As the Taxi-branco occurs in upland and lowland it was observed that the species prefers areas of predominantly top bioclimate with water deficit between 150 to $250 \mathrm{~mm}$, and elevations below $200 \mathrm{~m}$ altitude, next to the river, and the Parica in about $300 \mathrm{~m}$ altitude, and water deficit below $180 \mathrm{~mm}$. The knowledge of these zones should enhance the degree of confidence on the areas
\end{abstract}


indicated to the development of strategies for the genetic resources conservation and sustainable management of threatened tree species.

Keywords: preferential areas, top-bioclimate zoning, degraded landscape.

\section{Introduction}

In the Amazon, slash and burn practices, intense logging, expansion of agriculture and public policies of colonization and occupation can be identified as deforestation promoters in the region. The advance of deforestation may be linked to factors such as land tenure, extensive farming, illegal logging, weakness in law enforcement, lack of awareness of the population to report any irregularity, lack of commitment of the organizations that benefit from illegal products from native forest, illegal maneuvers that prevent agents that cause direct and indirect predatory deforestation from being held legally responsible for their acts and others. Depending on the magnitude of these the impacts can be intensified: loss of biodiversity, increased soil degradation, reduced carbon stocks in forest biomass, increasing emissions of greenhouse gases into the atmosphere and growth of the impoverishment of populations living in the Amazon.

The Brazilian Amazon has more than 5 million $\mathrm{km}^{2}$ with different climate conditions, and tends greatly towards agricultural expansion. Evaluating the results released by PRODES (Program for Monitoring the Brazilian Amazon Forest by Satellite), provided by the National Institute for Space Research INPE [1], it is observed that the eastern part of Para is the most deforested, indicating that there is strong human pressure with loss of forest cover. The agricultural expansion and illegal loggers have led to the extermination of populations of several species throughout the country (Carvalho [2]).

In areas already deforested in the Amazon, the agricultural research institutions have been studying and encouraging the adoption of production systems that adopt conservation practices, and bringing social, environmental and economic benefits to the region. Forest plantations of species with potential for energy, timber, veneer and plywood are presented as alternatives to silvicultural landscape restoration and maintenance of ecosystem services by the forest canopy. In this sense, it is recommended the inclusion of native species with fast growth, high biomass production, high economic value, supply of certified wood in areas of preferred top-climate [3-5], recommended to make arrangements in: agroforestry systems (Kato and Kato [6]); livestock-crop-forest; bragantino system, forest enrichment in areas protected by law, vegetation corridors, and other actions to redesign landscapes.

According to Filho et al. [7], forest management is the part of forestry science that deals with the set of principles, techniques and standards, which aim at organising, sorting and controlling the productivity and efficiency of the forest, keeping the structure of the forest and its ecosystem services, the maintenance of biological diversity and socio-economic development of a region. It is noteworthy that it is important to identify the type of intended use of the species, and market conditions favourable to their ecophysiological growth stages. 
Species can meet energy demands in isolated communities, both in raw material supply, the biomass as a source of renewable energy and mitigating emissions of greenhouse gases (Souza and Santos [8]).

Alvino et al. [9] found that of the 103 species native raised in a secondary forest with 30 years of age, in the Bragantina area in Para, 98\% of species have commercial value, while $33 \%$ fall into the categories of wood for rural constructions, $30 \%$ with high commercial value, $9 \%$ for wood production, $9 \%$ with low commercial value, $7 \%$ in the fruit category, $5 \%$ as medicinal species, $4 \%$ as timber for craft and $1 \%$ with potential resiniferous. Only $2 \%$ of the species studied did not fit into these categories. The potential of native timber in the region should be further investigated, since, according to Bentes-Gama et al. [10] one of the greatest obstacles to their use and effectiveness of market acceptance is the lack of more information about the ecophysiological species, technological characteristics and amount in forests subject to management (Scolforo et al. [11]).

In this work, we tried to focus our studies on two species native to the Amazon, the Taxi-branco (Sclerolobium paniculatum Vogel) and Parica (Schizolobium parahyba var. amazonicum (Huber ex Ducke) Barneby), which have the potential to produce energy and timber, respectively. The Taxi-branco (Caesalpinaceae) has potential energy, rapid growth, and fixed nitrogen in the soil and has high biomass production with financial returns in the short and medium term by providing high-quality coal products. According to Lorenzi [12] it is a semi deciduous, heliophytic, selective xerophytes plant and pioneer with an average density of $0.70 \mathrm{~g} \mathrm{~cm}^{-3}$ and has also shown potential for dye and honey varieties in dry regions (Silva Jr [13] and Thompson [14]). The Parica has softwood and lightweight, density of $0.40 \mathrm{~g} \mathrm{~cm}^{-3}$ with high market competitiveness when producing laminated wood and sheets of plywood, pressed and sintered, and its pulp is of good quality and suitable for the manufacture of paper and also has excellent resistance (Pereira et al. [15]).

In the city of Dom Eliseu, Para and its surroundings, the average productivity of Parica ranges from 25 to $30 \mathrm{~m}^{3} \mathrm{ha}^{-1} \mathrm{yr}^{-1}$ and the development of regional technologies provided greater efficiency, quality and standardization of rolled Parica regularity in the flow sale and consolidation of its supply chain in the state. Therefore, the objective was to evaluate the natural occurrence of these species associated with top-climate conditions, focusing on the productive context of sustainable management in the state of Para.

\section{Material and methods}

The data on the natural occurrence of the Taxi-branco and Parica was obtained from citations in the herbarium records of Embrapa Eastern Amazon, the Goeldi Museum and international databases [16], in addition to landscape data. Technical visits were made to areas of natural occurrence of these species and to plantations. Visits were made to the field, both in the city of Bragança and Dom Eliseu to evaluate natural occurrences and forest plantations. 
On the field trip to the city of Bragança the technical team was composed of parabotany, foresters, undergraduate students and agrometeorologiests. Botanical material was collected to make up the collection in the herbarium of EMBRAPA, recording the geographic position with the aid of GPS (Global Position System). It also, visited Taxi-branco crops farmers in the area of demonstration units in the project "Conservation and restoration of degraded landscape in units of family farming"-INOVAGRI / Embrapa Eastern Amazon/ ITTO/ABC. This project (PD. 346/05) assesses the progress of crops in mixed systems with forest species in a farm of 13 farming families. We analyzed the production of wood in different periods of harvesting areas averaged 0.36 ha and arrangements with 150 to 200 trees to establish indicators of reclamation or degradation pathway.

To record the natural occurrence of Parica the technical trip was made to Dom Eliseu and its surroundings, where arrays were mapped to identify areas of maintenance of genetic material capable of promoting expansion programs of forest plantations in the state of Para were also used data Census of Agriculture was also used available at the IBGE [17] website in the cities, regions to identify the production of wood and its derivatives.

In generating the top-climate maps we used data relief $(\mathrm{m})$, air temperature $\left({ }^{\circ} \mathrm{C}\right)$, rainfall $(\mathrm{mm})$ and soil water deficit $(\mathrm{mm})$. Water balances were estimated, considering the soil water capacity exceeding $300 \mathrm{~mm}$ (Thornthwaite and Mather [18]). The top-climate letters were prepared with spatial resolution of $3 \mathrm{~km} \mathrm{x}$ $3 \mathrm{~km}$ (3,840 points), specializing in ArcGIS 9.3 and exported to TerraView 3.2, creating the cell space for integration of variable and the model in the TerraME, fig.1.
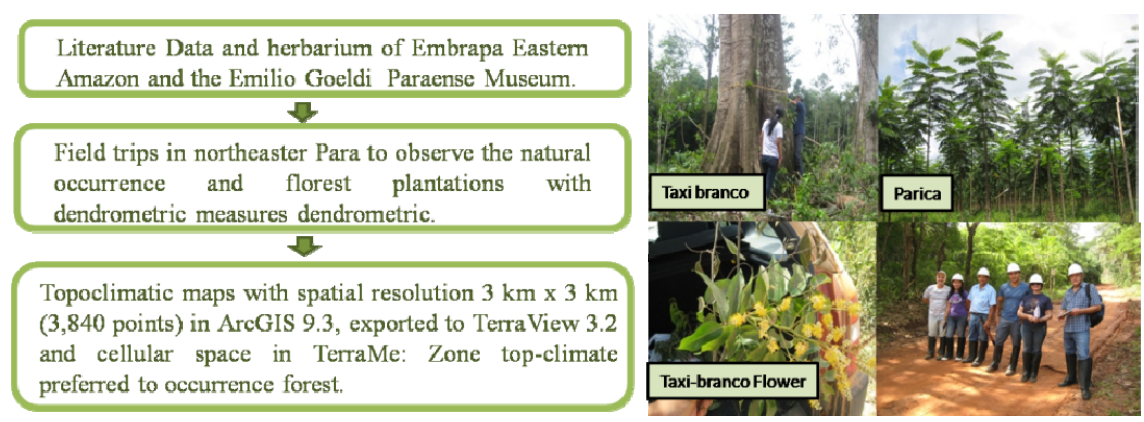

Figure 1: Methodology diagram.

\section{Result and discussion}

Observing the average annual data it appears that in the state of Para rainfall varies from 1,658 to 3,105, fig 2, and Bragança varies from 2,925 to 2,429 mm. During the month of March the wettest $(470 \mathrm{~mm})$ and October, the dry season, with monthly averages less than below $6 \mathrm{~mm}$, indicating a reduction of supply of rainwater to plants. The wettest quarter runs from February to April and the dry season from September to November, and the highest water deficits in soil in 
November $(110 \mathrm{~mm})$. The relative humidity has an annual average of around $85 \%$ to $90 \%$ in March and $76 \%$ in October.

The top-thermal annual conditions in the state of Para averages ranging from 23.3 to $27.5^{\circ} \mathrm{C}$ and Bragança ranging from 26.2 to $26.4^{\circ} \mathrm{C}$ with a maximum altitude of $100 \mathrm{~m}$, fig 3. From August to December, temperatures are higher $\left(26.7\right.$ to $\left.27.5^{\circ} \mathrm{C}\right)$. Joining the field information available in literature and found that the Taxi-branco flowering in northeastern Para occurs in December, the rainy season in the region, influenced by the Intertropical Convergence Zone effects.

Field observations confirm that the preferred ranges indicated by Brienza Jr. et al. [3], reinforcing the responses of species to top-bioclimate conditions. In the field dendrometric measurements in individual Taxi-branco, found near the town of Benevides, adults with DBH of $50 \mathrm{~cm}$ and height of $12 \mathrm{~m}$ were found. When considering the data obtained by Kanashiro and Yared [19] that there are increments in $S$. paniculatum $2.5 \mathrm{~cm} \mathrm{DBH}$ in forest plantations in the Amazon Basin, we infer an age of 20 years to plan mapped by the team. The trees were all found in the range indicated by preferential Brienza Jr. et al. [3], reinforcing the responses of species to weather conditions and climate.
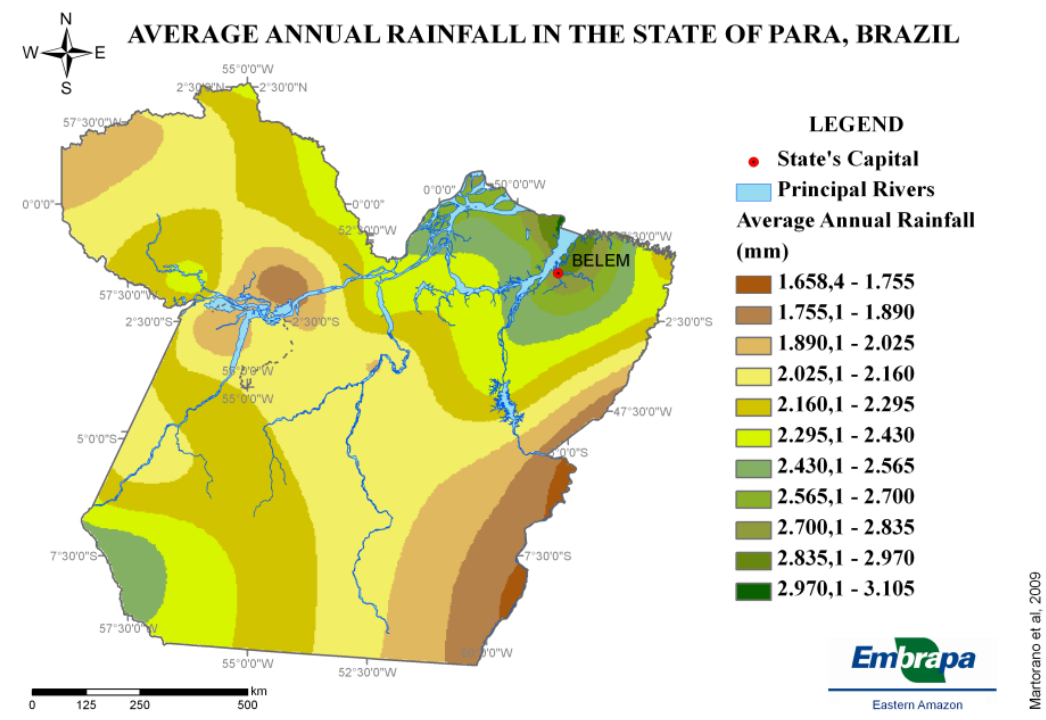

Figure 2: Annual rainfall in the state of Para, Brazil.

In Para, the areas where Taxi-branco occurred naturally were mapped, in the range of annual rainfall from 2160.0 to $2700.0 \mathrm{~mm}$ and Parica in areas between 2295.0 to $2430.0 \mathrm{~mm}$. In Dom Eliseu city the least rainy quarter is from June to August, and the wettest runs from February to April. In terms of thermal top observed values between 25.0 to $25.8^{\circ} \mathrm{C}$ and altitudes in the city can reach $400 \mathrm{~m}$. The annual relative humidity varies from 77 to $83 \%$ in the city as a 

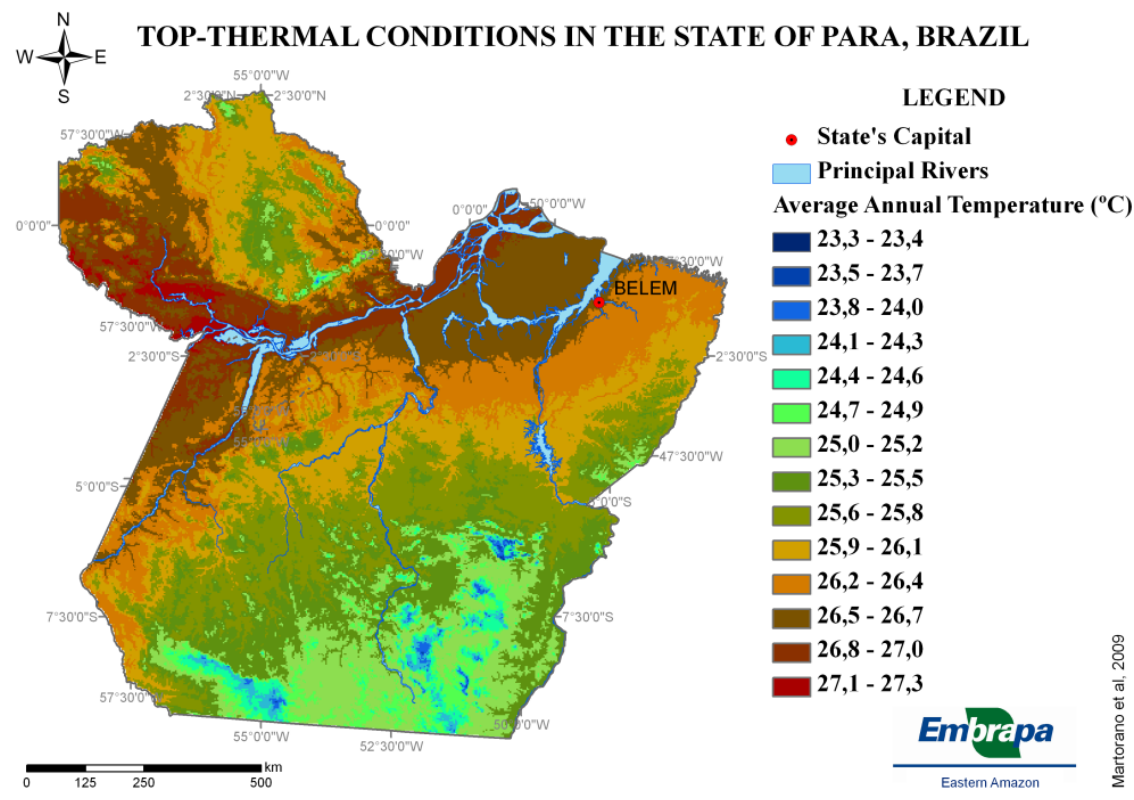

Figure 3: $\quad$ Top-thermal annual conditions in the state of Para, Brazil.

whole. It is observed that the lower values of relative humidity occur in October and range from 74 to $78 \%$. The moisture in the wettest month is from 88 and $90 \%$.

As the Taxi-branco occurs in upland and low land it was observed that the species prefers areas of predominantly top bioclimate with water deficit between 150 to $250 \mathrm{~mm}$ and elevations below $200 \mathrm{~m}$ altitude next to the river and the Parica in about $300 \mathrm{~m}$ altitude and water deficit below of the $180 \mathrm{~mm}$ Table 1. Despite the low number of individuals from Taxi-branco in the region investigated, the data shows that the top bio-climatic information can help indicate the preferred areas for planting this species in the northeastern region.

The knowledge of these zones should enhance the confidence degree in the areas appointed for the development of strategies for the genetic resources conservation and sustainable management of threatened tree species, fig. 4. This evidence corroborates the studies by Lima et al. [20] that the species occurs in a wide range of climate conditions.

Table 1: $\quad$ Forest species and top-climate conditions in the State of Para.

\begin{tabular}{c|c|c}
\hline Forest Species & $\begin{array}{c}\text { Altitude } \\
(\mathrm{m})\end{array}$ & $\begin{array}{c}\text { Water Deficit } \\
(\mathrm{mm})\end{array}$ \\
\hline $\begin{array}{c}\text { Sclerolobium paniculatum } \text { (Taxi- } \\
\text { branco) }\end{array}$ & 0 a 200 & 150 a 250 \\
\hline $\begin{array}{c}\text { Schizolobium parahyba } \text { var. } \\
\text { amazonicum (Parica) }\end{array}$ & 0 a 300 & $<180$ \\
\hline
\end{tabular}




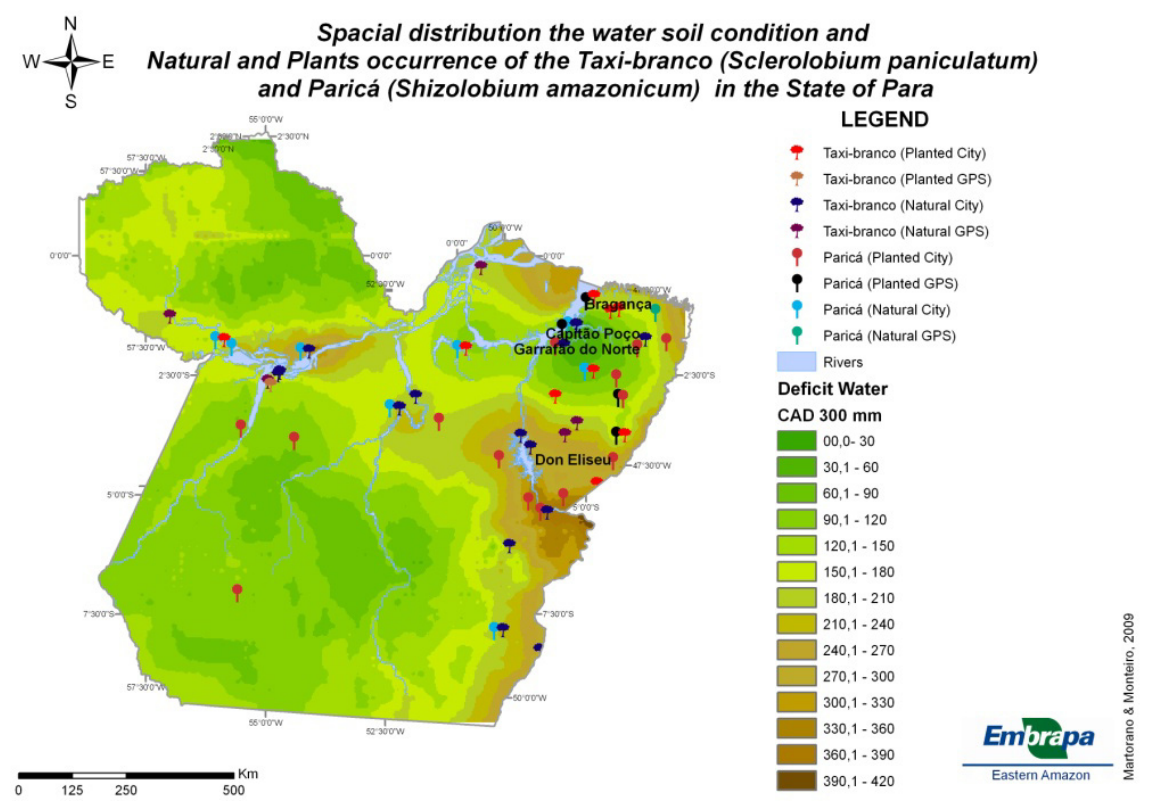

Figure 4: Tracks the soil water deficit and occurrence (natural and plantations) and Taxi-branco and Parica in Para.

Besides their wood producing and energetic potentials, these plants - which are native and largely found in the Amazon region - also produce pollen and nectar, and they are excellent to join the honey producing region in Para. In this way, the climatic change indication, such as years when the El Niño and the La Niña are in effect, will subside the honey producing strategies, because they directly associate the flowering season and the rain availability in the region.

Studies carried out by Embrapa Amazônia Oriental show that the Parica flowers are visited by numerous insects, and the more important for their polinization are medium to large bees (15 to $25 \mathrm{~mm}$ ). Among the Meliponíneos, the most common were the Trigona, the Scaptotrigona and the Melipona bees. Regarding the Taxi-branco, honey is found in small amounts, but very concentrated (containing medium amount of sugar: 82\%). Among the Meliponíneos, the most frequent were the Scaptotrigona and the Melípona (Embrapa [21]).

The preferred top-bioclimate zones of these species enhance the insertion strategies in altered areas which have lost much of their forest covering to the productive area, enabling the rural producers add other income sources to theirs, reducing the pressure in the areas.

Information made available by IBGE [17] found that in the northern region, only the states of Para and Amapa appear as suppliers of firewood products and roundwood products, producing in that year in Para $80000 \mathrm{~m}^{3}$ of fuelwood in 
Para, 1.5 million $\mathrm{m}^{3}$ of roundwood for pulp and $716,000 \mathrm{~m}^{3}$ for other purposes, financial support totaling around R\$ 143 million, from forestry products in the region.

From 2006 to early December 2010, Sisflora [22] Para was extracted and sold about $305,000 \mathrm{~m}^{3}$ of Taxi-branco (Sclerolobium paniculatum Vogel) and Parica (Schizolobium parahyba var. amazonicum (Huber ex Ducke) Barneby), accounting for around 15 million, the contribution of these two tree species was about 10 million dollars, adding jobs and income to the productive sector of the wood in the state, fig. 5 .

With regard to economic aspects, the information presented in, fig. 4 emphasises the importance of identifying top-climate areas preferred as indicators of potential areas for placement within these arrangements in forest in deforested areas.

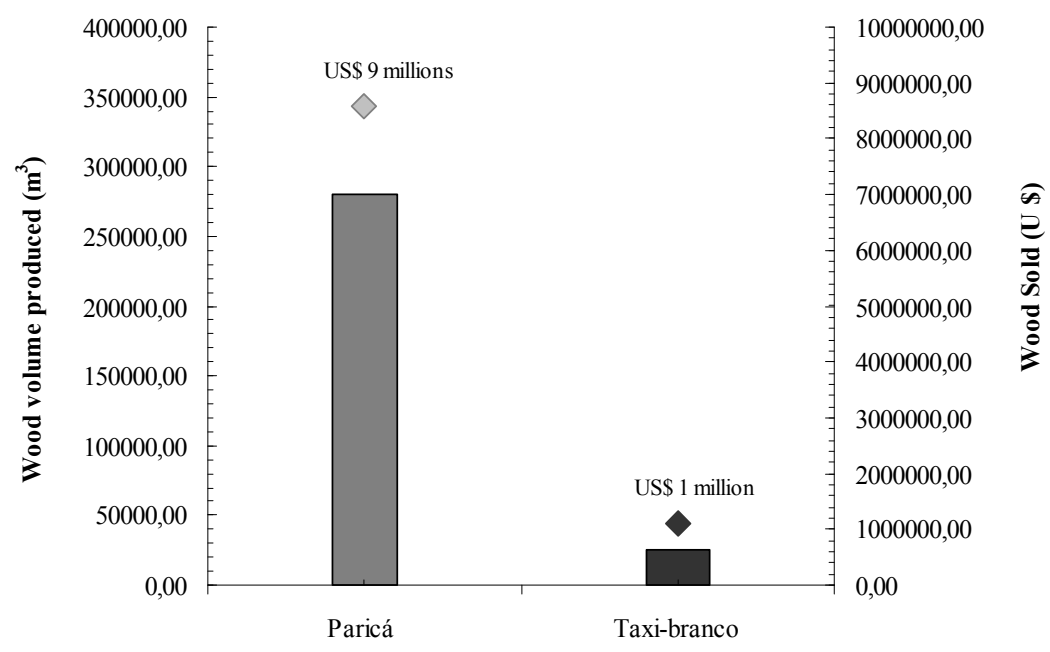

Figure 5: Average volume of production of Taxi-branco and Parica from 2006 to early December 2010 in the state of Para.

The data provided by INPE [1] to indicate that the state of Para lost nearly $20 \%$ of its forest cover. However, analyzing the percentage of deforestation in the state, it is noted that about $8 \%$ of that total is due to deforestation in northeaster Para, fig. 6. The transformation of forested lands by human actions represents one of the great forces in global environmental change and one of the great drivers of biodiversity loss with implications to life on this planet.

Fig. 7 shows that between 2005 and 2009 the deforestation in Bragança, Garrafão do Norte and Capitão Poço was around the $80 \%$. The use of these areas with forest plantations is a reduction in pressure on the forest, helps mitigating greenhouse gases, in addition to promoting supply of raw material to the 


\section{Deforestation and Forest Areas in the State of Para}

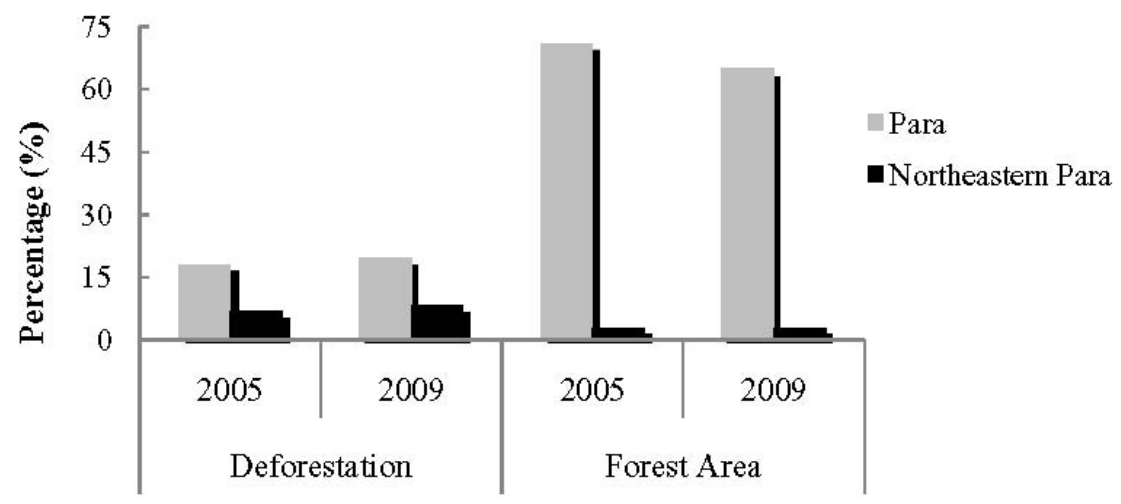

Source: PRODES - INPE(2009)

Figure 6: Percentage (\%) of deforestation and Forest Areas in the State of Para (2005 and 2009 years).

\section{Deforestation in cities of northeastern Para 2005 and 2009 years}

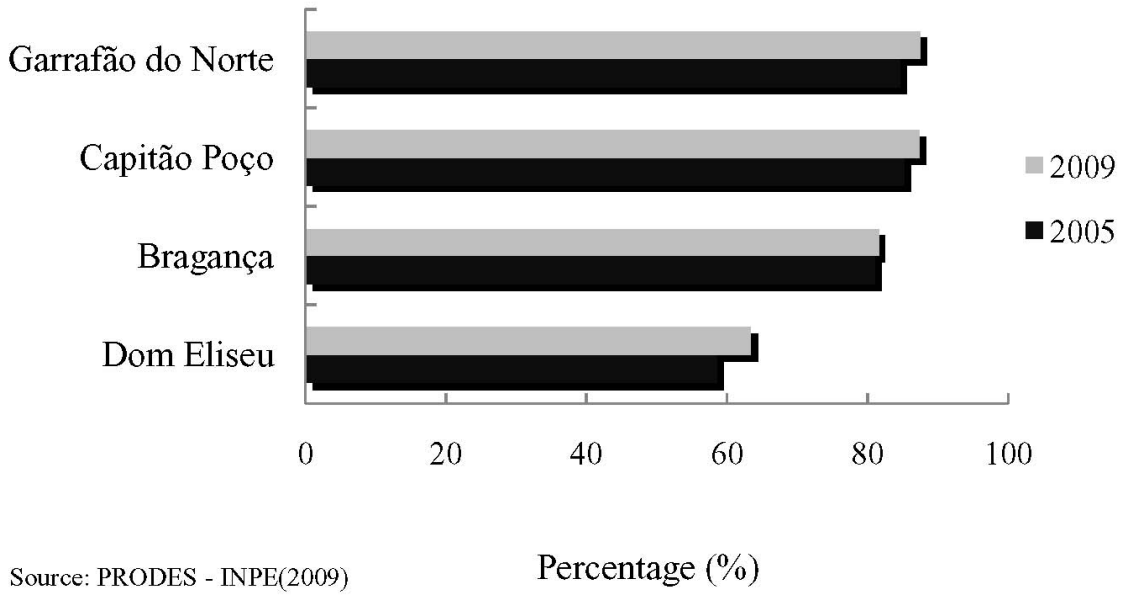

Figure 7: Deforestation percentage (\%) in the northeast of Para (2005-2009). 
productive sector of wood, veneer, plywood, charcoal and other forest products. Also in fig.7, it may be inferred from the apparent deforestation that it is due to the silvicultural system used in commercial forestry plantations in Dom Eliseu.

In this context, in these cities, since 2007, the potential energy of the Taxibranco in the recovery of degraded landscape, systems of mixed forest species, with different periods of harvest, were planted by 13 families of farmers. The average size areas is 0.36 ha and the used silvicultural model, where there is the mixing 150 to 200 trees of Sclerolobium paniculatum Vogel (Taxi-branco); Schizolobium parahyba var. amazonicum (Huber ex Ducke) Barneby (Parica) and other species.

\section{Conclusion and outlook}

The top-climate conditions show that there are areas with potential for expansion of forest plantations Taxi-branco and Parica, especially in areas with severe loss of vegetation cover as the northeast Para. Based on the data obtained it is recommended the planting of Taxi-branco and Parica in order to recover the degraded landscape with characteristics similar to top-climate areas presented in this paper.

Techniques of dynamic modelling and geomatic assist in identifying areas top-bioclimate are indicated to the development of strategies for the genetic resources conservation and sustainable management of threatened tree species.

The knowledge of these zones should enhance the confidence degree for establishment of forest plantations in the restoration of sustainable landscapes and the Amazon.

\section{Acknowledgement}

S. Brienza Jr. was supported by a grant from the Emílio Goeldi Museum, Brazil

\section{References}

[1] INPE. Instituto Nacional de Pesquisas Espaciais, Prodes, 2005-2009. $\mathrm{http} / / \mathrm{www} . o b t . i n p e . b r /$ prodes/

[2] Carvalho, P.E.R. Espécies Arbóreas Brasileiras. 1a edição. Colombo, PR Embrapa Florestas, 2003. Vol.1.

[3] Brienza Junior, S.; Monteiro, D.C.A.; Martorano, L.G.; Lisboa, L.S.; Maestri, M.P.; Schuler, A. Energetic potential of the Sclerolobium paniculatum Vogel (Taxi-branco) and its preferential top climatic condition in Eastern Amazon, Brazil. In: Conference on International Research on food security, Natural, Resource Management and Rural Development. HAMBURG: Alemanha, 2009.

[4] Martorano, L. G.; Brienza Junior, S.; Monteiro, D. C. A.; Lisboa, L. S.; Câncio, O.N.; Martorano, P.G.; Espirito Santo, J.M.do. Condições topobioclimáticas associadas à ocorrência de Taxi-branco (Sclerolobium 
panuculatum Vogel) e Paricá (Schizolobium parahyba var. amazonicum (Huber ex Ducke) Barneby) preferenciais para implantação de plantios florestais no Estado do Pará. In: XVIII Reunião Brasileira de manejo e conservação do solo e da água, 2010, Terezina, PI. Novos Caminhos para Agricultura Conservacionista no Brasil. Terezina : Piauí, 2010.

[5] Monteiro, D. C. A.; Martorano, L. G.; Brienza Junior, S.; Lisboa, L. S.; Ferreira, M.do.S.G.; Martorano, P.G. Condições Topobioclimáticas preferenciais para plantios energéticos de Taxi-Branco (Sclerolobium Paniculatum Vogel) na Amazônia Oriental Brasileira. In: $62^{\circ}$ Reunião Anual da Sociedade Brasileira para o Progresso da Ciência, 2010, NatalRN. Ciências do Mar: Heranças para o Futuro. Natal : Rio Grande do Norte, 2010.

[6] Kato, M.S.A; Kato, O.R. Preparo de área sem queima, uma alternativa para a agricultura de derruba e queima na Amazônia Oriental: Aspectos Agroecológicos. In: Seminário sobre manejo de vegetação secundária para a sustentabilidade da agricultura familiar na Amazônia Oriental. 2000, Belém. Anais...Belém, 2000, p.35-37.

[7] Filho, A.C.; Manzi, A.; Santos, J. dos; Rocha, R.M.; Higuchi, N. 2004. A Floresta e o Clima. In: A Floresta Amazônica e suas Múltiplas Dimensões: uma proposta de educação ambiental. P. 81. INPA/CNPq. 2004. 146 p.

[8] Souza, R.C. R.; Santos, E.C.S. Incentivo ao uso de Biomassa para a geração de eletricidade na Amazônia. III Congresso Brasileiro de Regulação dos serviços públicos concedidos. ABAR-Associação Brasileira de Agências de Regulação. Gramados, RS, 2003.

[9] Alvino, F. de O.; Silva, M. F. da; Rayol, B. P. Potencial de uso das espécies arbóreas de uma floresta secundária, na Zona Bragantina, Pará, Brasil. Acta Amazônica. v. 35, n. 4, p. 413-420, 2005.

[10] Bentes-Gama, M. de M.; Scolforo, J.R.S.; Gama, J.R.V.; Oliveira, A.D. Estrutura e valorização de uma floresta de várzea alta na Amazônia. CERNE, 8 (1): 88-102.2002.

[11] Scolforo, J. R. S. ; Peres, J. F. M. ; Melo, J. M. ; Oliveira, A. D. ; Camolesi, J. F. ; Borges, L. F. R. ; Acerbi Junior, F. W. . Estimativas de volume, peso seco, peso de óleo e quantidade de moirões para a candeia (Eremanthus erythropappus (DC.) MacLeish).. CERNE (UFLA), v. 10, p. 87-102, 2004.

[12] Lorenzi, H. Árvores Brasileiras: Manual de identificação e cultivo de plantas arbóreas nativas do Brasil. v.2. São Paulo: Editora Plantarum. 1998.

[13] Silva Júnior, M. C. da. 100 árvores do Cerrado: guia de campo. Editora Rede de Sementes do Cerrado. Brasília, 2005. 278 p.

[14] Thompson, R. M. Estimativa de Volume, biomassa e carbono para Esclerolobium paniculatum Vogel. 64p.(Dissertação de Mestrado) UnBBrasilia, 2009.

[15] Pereira, A. P., Melo, C. F. M. de, Alves, S. M. O Paricá (Schizolobium amazonicum) características gerais da espécie e suas possibilidades de aproveitamento na indústria de celulose e papel. Revista do Instituto Florestal, São Paulo, v. 16 A, n 2. p. 1340-1344, 1982. 
[16] GBIF - Global Biodiversity Information Facility. http://data.gbif.org /species

[17] IBGE. Instituto Brasileiro de Geografia e Estatística. Senso Agropecuário 2006. http//www.ibge.gov.br

[18] Thornthwaite, C.W.; Mather, J.R. The water balance. Publications in Climatology. New Jersey: Drexel Institute of Technology, 104p. 1955.

[19] Kanashiro, M.; Yared, J. A. G. Experiências com plantios florestais na Bacia Amazônica. In: Universidade Federal do Paraná. O desafio das florestas neotropicais. Curitiba: UFPR, 1991. p. 117-137.

[20] Lima, R. M B. de; Azevedo, C. P de; Rossi, L. M. B; Garcia, L. C. Crescimento de Sclerolobium paniculatum Vogel na Amazônia, em função de fatores de clima e solo. Tese...UFPR, Curitiba, 2004.

[21] EMBRAPA - http://mel.cpatu.embrapa.br/plantas.

[22] Sisflora/SEMA. http//monitoramento.sema.pa.gov.br/sisflora/ 